\title{
Combined therapy using fetal stem cells and a complex of physical exercises in treatment of patients with amyotrophic lateral sclerosis
}

\author{
A.A. Sinelnyk1, M.O. Klunnyk1, M.P. Demchuk1, N.S. Sych1, O.V. Ivankova1, I.G. Matiyashchuk1, M.V.Skalozub2, A.V. Novytska1 and \\ K.I. Sorochynska3 \\ ${ }^{1}$ Clinical Department, Cell Therapy Center EmCell, Kyiv City, Ukraine \\ ${ }^{2}$ Laboratory and Biotechnology Department, Cell Therapy Center EmCell, Kyiv City, Ukraine \\ ${ }^{3}$ Stem Cells Bank, Cell Therapy Center EmCell, Kyiv City, Ukraine
}

\begin{abstract}
To analyze the parameters including data of disease progression, muscles power subsidence, life expectancy, functional independence and rates of cognitive disturbances, which were obtained during observation of the patients with amyotrophic lateral sclerosis (ALS) who were administered a combined therapy by use of fetal stem cells (FSCs) extracted from human fetuses with 5-10 weeks of gestation along with a complex of bodily exercises within the whole period of the follow-up. A comparative study of 56 patients suffering from different forms of ALS was performed. The main group (MG) included 30 patients who were administered a combined treatment comprising the individual program with a complex of kinesiotherapy, respiratory gymnastics and transplantation of suspensions containing fetal stem cells (FSCs) harvested from fetal liver and brain of human fetuses with 5-10 weeks of gestation over the period of observation. The control group (CG) constituted 26 patients who followed their individual programs including a complex of kinesiotherapy and respiratory gymnastics during observation. The patients in both groups were compared according to the sex, age and the forms of ALS disease. Significant slowdown of the course of ALS disease and prolongation of average life expectancy was reported over a period from 6 to 18 months after treatment among the patients of the MG in comparison with the patients of the CG. Suggested method of treatment encourages searching for more effective management of ALS and extension of life expectancy in the patients, even though, it demands maintenance of further clinical studies.
\end{abstract}

Combined treatment of ALS including the individual program with a complex of kinesiotherapy, respiratory gymnastics and administration of FSCs suspensions proved to objectively inhibit a progression of ALS over the period from 6 to 18 months from the beginning of treatment and contributes to longer life expectancy among the patients.

\section{Introduction}

Amyotrophic lateral sclerosis (ALS) or motor neuron disease (MND) is an idiopathetic progressive neurodegenerative disease with a random primary neuronal degeneration of the upper motor neurons (UMN) and the lower motor neurons (LMN) resulting in progressive atrophy of bulbar, limb, thoracic and ventral muscles which is associated with fasciculation, spasticity and the other manifestations. Cognitive disturbances are detected in $20-50 \%$ of the patients. Mortality outcome related to respiratory failure on average occurs within 2-4 years after disease onset, though a moderate number of patients up to $7 \%$ are still likely to reach a five-year survival rate or even more. Approximate disease prevalence rate makes up 6-8 patients per 100000 individuals. $5-10 \%$ of the patients report a hereditary character of disease, whereas the causes of the other sporadic cases remain unknown. [1,2]. A great deal of studies are directed at clarification of the causes and pathogenesis of ALS [3-10]. Nowadays, several mechanisms are known to be likely connected with ALS disease progression: glutamate excitotoxicity, oxidative stress, disorganization of neurofilaments, deficit of neurotrophic factors, dysfunction of mitochondria and the other organelles, reactive astrocytosis, and familial (fALS) mutations of the $\mathrm{Cn}^{2+} / \mathrm{Zn}^{2+}$ superoxide dismutase 1 (SOD1), TDP-43, FUS, or C90ORF72 genes [3-5,11-13]. With due account for unclear trigger mechanisms of ALS, etiological therapy has not been established until presently. Treatment of the underlying disease is primarily directed at inhibition of excitotoxicity by decreasing synthesis and metabolism of glutamate, suppressing post-synaptic NMDA-receptors of glutamate and having a direct impact on the complex intracellular cascades. For present time riluzole (Rilutek ${ }^{\mathbb{}}$ ) is the only medicine available for clinical application which is likely to prolong the patient's life over 3 months on average [14-18]. Neurotrophic factors use has been recently considered as a perspective method for pathogenetic treatment. In this regard glatiramer acetate, cerebrolysin and some other medical drugs are prescribed for the patients, though, there is no unequivocal estimation regarding their effectiveness. For this very reason of minor therapeutic modality and side effects related to medicines, development

Correspondence to: A.A. Sinelnyk, MD, Neurologist, Cell Therapy Center EmCell, 50apt.68, Korolenko str, 07400, Brovary Town, Kyiv Region, Ukraine, Tel: +38 0442232895 Cell: +38 06888989 89;; E-mail: infocenter@emcell.com

Key words: amyotrophic lateral sclerosis, average life expectancy, fetal stem cells, handheld dynamometry

Received: October 20, 2015; Accepted: November 09, 2015; Published: November 13, 2015 
of present-day and effective ways of treatment is a challenging trend of ALS therapy.

Stem cells therapy is one of the promising approaches in treatment of ALS and the scientists in many countries impose expectations on it. Stem cells are prone to differentiating into various types of cells and can enable regeneration and even replacement of cells of neural tissue [19]. Stem cells administration as anticipated can result in replacement of the affected motor neurons or neural cells in ganglia and tend to maintain a sustaining, trophic function in particular and ultimately contribute to restoration of neuromuscular function which has been lost or impaired [20]. Among the multiple types of stem cells used for studies embryonic differentiated neural stem cells, induced pluripotent and mesenchymal stem cells (MSCs) have been frequently used [21]. At present clinical studies approved by FDA are established and are goaled at treatment of the patients with ALS [22,23].

The mechanisms of influence of stem cells on the human organism are regarded at different levels. Firstly, this suggests replacement and restoration of the cells lost; an impact of trophic factors or genes delivery and eventually immunomodulation [24]. Although capacity of the transplanted mesenchymal stem cells and their differentiation into the neuronal phenotypes has been proved in several studies, the therapeutic vector of these achievements remains ambiguous $[25,26]$. Despite of a characteristic feature of ALS - loss of primary motor neurons, there are distinguishing features on a large scale which identify dysfunction of ganglia as significant in this disease pathogenesis. Therefore, glial cells enrichment for the purpose of neuroprotection is likely to become our secure and effective goal. Efficacy of MSCs in improvement of treatment outcomes among the patients suffering from ALS could be attributable to secretion of neurotrophic factors which execute regulatory and neurorestoration functions. Neurotrophic factors are valuable peptide structures affecting the functions, differentiation and proliferation of neural stem cells. GDNF, VEGF, IGF-1 are likely to rouse a particular interest in ALS neuroprotection [27-29]. Migration of MSCs into the sites of affected tissues and focal accentuation of trophic factors may invole the effects of endogenic recovery, induction of endogenic neurogenesis, gliogenesis and synaptogenesis in particular [30,31].

Plenty of studies and clinical trials have been recently undertaken based on straightforward transplantation of MSCs into the spinal marrow. Cellular migration of MSCs out of the site of injection in the lumbar region of spinal cord toward the ventral parts located in a close proximity to motor neurons has been established [32-34]. In spite of absence of substantial complications related to this mode of administration, less invasive methods for MSCs application have been developed in treatment.

There is an increasing evidence in regard to the systemic, but not solely autonomic cellular mechanisms of neurodegeneration in ALS which argue for potential expedient and systemic extracerebral administration of MSCs [35, 36]. Thus, positive results were obtained after MSCs application by way of intravenous infusion on ALS models in mice [37-39]. In preclinical studies, MSCs were administered by intramuscular injections. With regard to the above mentioned there is a likely advantage of this mode of administration principally due to immediate proximity to the affected area without need to directly interfere with CNS $[40,41]$.

Muscle activity is one more mechanism of physiology influence on neurotrophic maintenance. As a result, regular bodily exercises are prone to enhance a production of endogenic growth factors. In order to attain maximal therapeutic efficacy, physical exercises were conducted on the experimental models with ALS for the purpose of increasing delivery of the factor. Subsequently the clinical studies identified a favorable impact of bodily exercises on the patients [42- 53].

\section{Materials and methods}

56 patients suffering from ALS have been studied in Cell Therapy Center EmCell. Among the patients under study 30 (53.6\%) individuals revealed a cervical-thoracic form of ALS, 15 (26.8\%) persons reported a bulbar form of the disease and 11 (19.6\%) - suffered from a lumbosacral form of ALS. The interval between the primary clinical manifestations and established diagnosis constituted $10.6 \pm 2.8$ months in all patients. The patients were allocated into 2 groups where the MG included 30 individuals with the average age of $41.1 \pm 6.1$ years, 18 (60.0\%) among them were men and $12(40.0 \%)$ - women. The CG was composed of 26 patients with average age of $49.3 \pm 5.8$ years, including $15(58.0 \%)-$ men and $11(42.0 \%)$ - women. Both groups were compared according to the sex, age and form of disease and the patients did not undergo any specific treatment.

Inclusion criteria for the study of the patients were the following: verified diagnosis of ALS, in conformity with the "revised El Escorial criteria" (1998), spirometry indices (FVC) not less than 30\%, and the parameter of body mass index (BMI) - not less than $18.5 \mathrm{~kg} / \mathrm{m}^{2}$. Apart from that the study group did not include the patients suffering from cardiovascular diseases in the phase of decompensation and likely complications in the past history (myocardial infarction, cerebral stroke), decompensated kidney and liver insufficiency, traumatic brain or spinal cord injuries in anamnesis, as long as without any proof of blood coagulation disturbances of whatsoever genesis or presence of malignant malformations. Prior to the study all patients were evaluated to determine cognitive functions in accordance with the scale of minimental state examination (MMSE) [54].

ALSFRS-R scale was applicable for assessment of the patients' state in dynamics $[55,56]$. A quantitative testing score to determine muscles power was used as a measure for evaluation of ALS disease progression [57,58]. Assessment of maximal voluntary isometric contraction (MVIC) substantiated the method reliability, accuracy and susceptibility for quantitative evaluation of muscles strength $[59,60]$. The measured muscle strain has been considered as quantity in kilograms (kg.), exercised by the patient against the strain gauge. All measurements were made in a standardized manner for assessment of indices of power in the digital flexor muscles of hands by use of handheld dynamometry (HН-Dyn) (dynamometer_ДМЭР-30, Russian Federation 2005).

The patient's assessment according to the scale of functional independence measure (FIM) [61] was made immediately before treatment and the individual complex of physical exercises (kinesiotherapy, respiratory gymnastics) was generated with consideration of physical capacities in the patients.

All patients in both groups performed a complex of physical exercises according to individual program over the whole period of the study. Correction of the complex of physical exercises was made over 6,12 and 18 months after beginning of follow-up. The patients of the MG received FSCs suspensions harvested from the cadaveric tissues of fetal liver and brain extracted from the medically aborted human fetuses with 5-10 weeks of gestation; pursuant to family planning and social purposes without any developmental pathology or infections confirmed. All donors were practically healthy women and 
had negative test results for hemic infections. The patients had their informed consent signed before treatment.

Biotechnology process of suspension preparation included: cells separation from different growth zones in human fetus (liver, brain); assessment of cells viability and programmed cryopreservation; testing for bacterial and viral infections. Cryopreservation was made by use of $5 \%$ dimethyl sulfoxide (DMSO) as cryoprotectant and dextran-40 to pursue the 3-stage program for freezing at the initially adjusted speed of $1^{\circ} \mathrm{C} / \mathrm{min}$ and crystal forming initiation.

Defrost of cryopreserved suspension was made by water bath thawing at temperature $37.5^{\circ} \mathrm{C}$ immediately before to administer FSCs and cells viability was controlled. Then fetal stem cells viability was tested by trypan blue staining and cells were counted using 2 methods in parallel: Goryaev chamber and Automated Cell Counter NC-100 (Nucleo Counter Type 900-004 Chemo Metec, Denmark 2010). Cells viability before freezing made up $83.0 \pm 3.0 \%$. Right after cryopreservation in low temperature $\left(\mathrm{t}-196^{\circ} \mathrm{C}\right)$ cryobank and water bath thawing of cryopreserved suspension at $37.5 \pm 0.1^{\circ} \mathrm{C}$ cells viability accounted for not less than $74.8 \pm 1.0 \%$.

Fetal stem cells were administered during 2 days: fetal liver stem cells drip-feed intravenous infusion using $0.9 \%$ sodium chloride solution was supplied on treatment day 1 ; fetal brain stem cells were injected subcutaneously into the anterior abdominal wall during the treatment day 2. Volume of therapeutic dose of fetal liver was not less than $0,1 \mathrm{~mL}$ of cells in suspension with the nucleated cells count not less than $2.64 \times 10^{6} / \mathrm{mL}$ per transplantation and cells precursors CD34+ ranged from 0.4 to $2.42 \times 10^{6} / \mathrm{mL}$ per one injection. Treatment dose of fetal brain cells was individually selected and made up not less than 0,1 $\mathrm{mL}$ of cells in suspension with the nucleated cells count of $1.05 \times 10^{6} / \mathrm{mL}$ per transplantation and cell precursors of CD34+ made up from 0.4 to $2.42 \times 10^{6} / \mathrm{mL}$ per one injection. Stem cells viability in the suspension corresponded to $70.0 \pm 10.0 \%$ [62].

Analysis of all values was made before treatment and over 6, 12, 18 and 24 months after stem cells administration. Statistical results processing was fulfilled using software Statistica v.6.0 (StatSoft Inc., Tulsa, USA) with calculation of the mean values and standard deviation. Significant difference between the scores was evaluated by use of the Student's t-test (for parametric statistics).

\section{Results and discussion}

The patients in the MG demonstrated insignificant statisticallyvalid negative dynamics over 6 months after treatment, the value in accordance with ALSFRS-R scale made up $28.12 \pm 1.32$ scores, if compared to the baseline $29.52 \pm 1.40$ scores, $(p<0.05)$. Notable stabilization of indices and none deterioration among the patients was reported over 12 and 18 months - both according to the ALSFRS-R scale, (Table 1) and in accordance with the patients' subjective assessment if compared to the previously recorded rate on the $6^{\text {th }}$ month after observation $-28.12 \pm 1.32$ scores, $(\mathrm{p}>0.05)$. However, the value on the ALSFRS-R scale over 24 months corresponding to 24.03 \pm 1.58 scores shown the evidence of significant negative dynamics if compared to the baseline $29.52 \pm 1.40$ scores, and similarly due to the parameters of previous study over 18 months $-27.98 \pm 1.40$ scores $(\mathrm{p}<0.05)$. Simultaneously after analysis of the scores in the CG within the whole period of the study significant negative dynamics is recorded both in comparison with the baseline and values in the MG (Table 1). Based on the results recorded one can conclude that combined treatment with inclusion of the individual program using a complex of kinesiotherapy, respiratory gymnastics and transplantation of FSCs promotes a slowdown of ALS disease progression over a period from 6 to 18 months after treatment initiation. However, such a tendency to progression is likely to be preserved among the patients and this becomes significant over 24 months of the study $(\mathrm{p}<0.05)$.

The next stage of our study consisted in investigation of changes in cognitive deficit among the patients with ALS according to the MMSE scale. The parameters of cognitive skills among the patients of the MG were stable and no significant changes were demonstrable within the whole period of observation if compared to the baseline $-28.69 \pm 0.78$ scores, $(\mathrm{p}>0.05)$ (Table 1). Almost zero dynamics both in conformity with the testing scores on the MMSE scale, and according to the subjective assessment of the patients proved absence of any negative cognitive disruptions in the patients who underwent combined therapy. The scores on the cognitive skills scale among the patients in the CG revealed a gradual negative dynamics over the whole period both in comparison with the data baseline and the corresponding indices in the MG ( $>0.05)$ (Table 1$)$. Information obtained is likely to indicate a positive effect of combined therapy in prevention of cognitive functions impairment among the patients with ALS.

According to our statistic data, average life expectancy in the patients with ALS remains within the range of 15.7-47 months [63,64], the mean value constitutes 39.2 months from disease onset and 30.6 months - from the moment of diagnosis making [65]. The average time interval between diagnosis and initiation of treatment for the patients under study corresponded to $11.9 \pm 4.2$ months. Over time after the study for the patients in the MG no cases of lethal outcome were reported. An average rate of life expectancy in the patients from the moment of diagnosis confirmation made up $35.9 \pm 4.2$ months. In

Table 1. Dynamics of the scores over the period of the study.

\begin{tabular}{|c|c|c|c|c|c|c|c|c|c|c|}
\hline \multirow[t]{2}{*}{$\begin{array}{l}\text { Scale, } \\
\text { scores }\end{array}$} & \multicolumn{2}{|c|}{ Prior to treatment } & \multicolumn{2}{|c|}{ Over 6 months after treatment } & \multicolumn{2}{|c|}{$\begin{array}{c}\text { Over 12months after } \\
\text { treatment }\end{array}$} & \multicolumn{2}{|c|}{$\begin{array}{c}\text { Over 18months after } \\
\text { treatment }\end{array}$} & \multicolumn{2}{|c|}{ Over 24 months after treatment } \\
\hline & MG & $\mathrm{CG}$ & MG & CG & MG & $\mathrm{CG}$ & MG & $\mathrm{CG}$ & MG & $\mathrm{CG}^{*}$ \\
\hline $\begin{array}{l}\text { ALSFRS-R, } \\
\quad \mathrm{M} \pm \mathrm{m}\end{array}$ & $29.52 \pm 1.40$ & $28.98 \pm 1.54$ & $28.12 \pm 1.32^{\#}$ & $26.72 \pm 1.61$ & $28.63 \pm 1.20^{\#}$ & $25.02 \pm 1.33$ & $27.98 \pm 1.40^{\#}$ & $21.18 \pm 1.12$ & $24.03 \pm 1.58^{\#}$ & $21.15 \pm 1.01$ \\
\hline $\begin{array}{l}\text { MMSE, } \\
\mathrm{M} \pm \mathrm{m}\end{array}$ & $27.39 \pm 0.78$ & $27.96 \pm 0.82$ & $27.86 \pm 0.92$ & $27.12 \pm 0.86$ & $27.55 \pm 0.68^{\#}$ & $26.65 \pm 0.78$ & $27.03 \pm 0.48^{\#}$ & $26.01 \pm 0.78$ & $27.09 \pm 0.80^{\#}$ & $25.23 \pm 0.51$ \\
\hline $\begin{array}{l}\mathrm{FIM}, \\
\mathrm{M} \pm \mathrm{m}\end{array}$ & $107.25 \pm 1.41$ & $105.15 \pm 1.83$ & $105.05 \pm 1.53^{\#}$ & $103.45 \pm 1.23$ & $104.95 \pm 1.32^{\#}$ & $102.35 \pm 1.42$ & $103.95 \pm 1.44^{\#}$ & $81.95 \pm 1.44$ & $96.92 \pm 1.35^{\#}$ & $80.92 \pm 1.35$ \\
\hline
\end{tabular}

Note:

*A number of patients diminished as a result of 3 patients who passed away.

${ }^{*} \mathrm{p}<0.05$ in comparison with the CG or the data baseline 
the meantime 3 patients of the CG died on the $19^{\text {th }}, 20^{\text {th }}$ and $23^{\text {rd }}$ month of observation, respectively. Respiratory failure on the background of bulbar form of ALS was the cause of mortality outcome in all cases. Death rate in the CG within the whole period made up $12.5 \%$. The results received indicate the prolonged average life expectancy among the patients of the MG, both in comparison with the CG and in accordance with overall statistics (all $\mathrm{p}<0.05)$.

Analysis of functional dependence by the Functional Independence Measure (FIM) scale in ALS patients of the MG over 6 months post treatment refers to $105.05 \pm 1.53$ scores in comparison with the baseline $107.25 \pm 1.41$ scores which is indicative of significant tendency to selfcare deterioration among the patients $(\mathrm{p}<0.05)$. The same negative dynamics was reported among the patient in the CG. Over 6 months after the study the value of $103.45 \pm 1.23$ compared to the baseline $105.15 \pm 1.83$ scores highlights a statistically significant negative pattern in self-care deterioration among the patients $(\mathrm{p}<0.05)$. By comparison of the scale parameters in patients of the CG over 12 months which constitute $102.95 \pm 1.32$ scores and the previous rate of $105.05 \pm 1.53$ scores, stabilization of the disease course is demonstrable which still remains after assessment of the patients over 18 months $-103.95 \pm 1.44$ scores, however, it reveals negative dynamics which is not significant. At the same time negative significant dynamics is preserved in the CG over 12,18 months if compared to the baseline $(\mathrm{p}<0.05)$, (Table 1$)$. In comparison of the scores in the MG and CG over 18 months and the corresponding results reported over 24 months, significant negative dynamics can be observed in both of the groups $(\mathrm{p}<0.05)$ (Table 1). The scores in the MG and CG over 24 months present significantly worse values at the moment of study termination among the patients in the CG $(\mathrm{p}<0.05)$ (Table 1$)$. The results received justify that combined treatment is likely to maintain functional independence of ALS patients of the MG during a period from 6 to 18 months and values remain significantly higher compared to the CG over 24 months (all $\mathrm{p}<0.05)$ (Table 1).

After correlation of handheld dynamometry (HH-Dyn) data in the MG over 6 months after treatment $\mathrm{RS}=23.99 \pm 1.14 \mathrm{~kg}$ and $\mathrm{LS}=19.81$ $\pm 1.17 \mathrm{~kg}$ with the baseline scores $-\mathrm{RS}=24.87 \pm 1.06 \mathrm{~kg}$. and $\mathrm{LS}=20.11$ $\pm 1.12 \mathrm{~kg}$, significant tendency to power subsidence in digital flexor muscles of both hands is demonstrable which has been proved by a subjective assessment of the patients (all $\mathrm{p}<0.05)$. Significantly negative dynamics of power subsidence in digital flexor muscles of both hands is also observed in correlation between the HH-Dyn data of the CG over 6 months after treatment RS $=21.19 \pm 1.09 \mathrm{~kg} ; \mathrm{LS}=18.01 \pm 1.11 \mathrm{~kg}$ and the scores baseline RS $=23.21 \pm 1.12 \mathrm{~kg} ; \mathrm{LS}=19.98 \pm 1.16 \mathrm{~kg}$, which has been also proved by a subjective assessment of the patients (all $\mathrm{p}<0.05$ ). The same tendency is preserved at correlation of the scores in the CG both over 12 months $\mathrm{RS}=20.27 \pm 1.24 \mathrm{~kg}$; $\mathrm{LS}=16.62 \pm 1.16 \mathrm{~kg}$ compared to the rates over 6 months after treatment, and over a period of 18 months $\mathrm{RS}=19.07 \pm 1.13 \mathrm{~kg} ; \mathrm{LS}=16.13 \pm 1.11 \mathrm{~kg}$ if compared to the results received over 12 months (all $\mathrm{p}<0.05$ ) (Figure 1). By correlation of the HH-Dyn data in the MG for the period over 6 months RS=23.99 \pm 1.14 $\mathrm{kg}$ and $\mathrm{LS}=19.81 \pm 1.17 \mathrm{~kg}$ and the results received over 12 months $\mathrm{RS}=23.67 \pm 1.07 \mathrm{~kg}$ and $\mathrm{LS}=19.62 \pm 1.23 \mathrm{~kg}$ stabilization of power in digital flexor muscles of both hands is observed without significantly proved dynamics (all $\mathrm{p}>0.05$ ). The same tendency is preserved in correlation of the scores of the MG over 12 months RS=23.99 $\pm 1.14 \mathrm{~kg}$ and $\mathrm{LS}=19.81 \pm 1.17 \mathrm{~kg}$ and the results obtained over 18 months after treatment beginning (all $\mathrm{p}>0.05$ ).

Among the patients of both groups significant tendency to power subsidence in digital flexor muscles of both hands is preserved over a

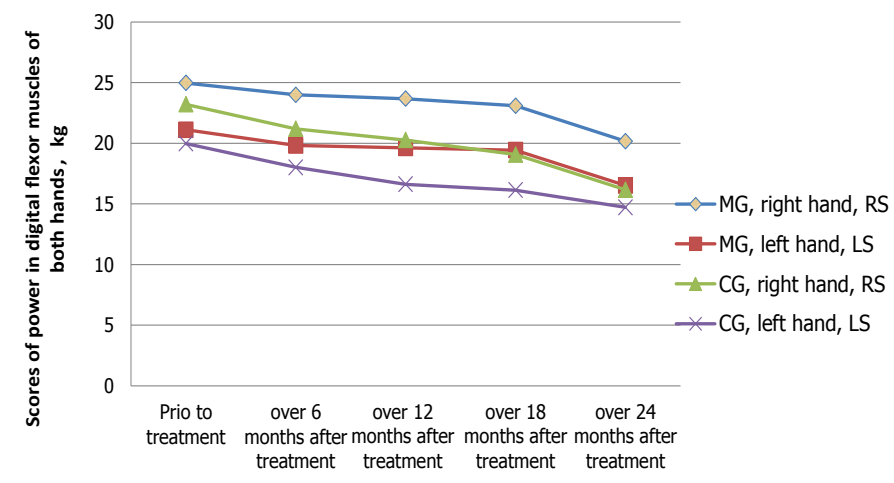

*Legend: RS-right side; LS-left side

Figure 1. Dinamics of scores after the study and scores of power in digital flexor muscles of both hands.

period from 18 to 24 months which has been proved by a subjective assessment of the patients $(\mathrm{p}<0.05)$ (Figure 1). Although, correlation of the scores in the MG $(\mathrm{RS}=20.17 \pm 1.20 \mathrm{~kg}$; $\mathrm{LS}=16.52 \pm 1.19 \mathrm{~kg})$ and the CG (RS=16.17 $\pm 1.21 \mathrm{~kg}$; LS $=14.72 \pm 1.16 \mathrm{~kg}$ ) over 24 months suggests significantly worse values at time of termination of the study among the patients in the CG $(\mathrm{p}<0.05)$. The results received identify a slowdown of subsidence in power of digital flexor muscles as a group of body muscles which are frequently involved in ALS over the period from 6 to 18 months after stem cells administration and completion of the individual program with a complex of kinesiotherapy and respiratory gymnastics $(\mathrm{p}<0.05)$.

In consequence, ALS patients who underwent FSCs treatment and completed the individual program with a complex of kinesiotherapy and respiratory gymnastics over a period from 6 to 18 months reported a slowdown of disease progression and delayed subsidence in muscles power of digital flexor muscles of both hands, for instance, due to both objective and subjective assessment; they also demonstrated longer life expectancy, functional independence and prevention of cognitive functions deterioration.

Nevertheless, we understand that informative base of the study is not enough for a broad clinical application of this method. In the course of the study (24 months) after administration of FSCs, we did not observe any adverse effects which are likely to affect the functions of the brain and cardiovascular system and no clinical cases of allergy reactions were reported among the patients. Therefore, one can speak about safety of all further long-term observations. Suggested method of treatment raises great expectations for more effective treatment of ALS, though it requires future follow-up.

\section{Conclusions}

Combined therapy with inclusion of FSCs treatment along with the individual program of a complex of kinesiotherapy and respiratory gymnastics is safe and effective method directed at slowdown of ALS progression during a period from 6 to 18 months and results in prolongation of average life expectancy among the patients, (all $\mathrm{p}<0.05$ ). Combined therapy including FSCs transplantation along with the individual program of a complex of kinesiotherapy and respiratory gymnastics positively effects cognitive function of the patients with ALS both according to the results on the MMSE scale and due to a subjective assessment of the patients and reports lack of negative cognitive impairments over 24 months after the study, (all $\mathrm{p}<0.05)$. The results of handheld dynamometry analysis demonstrate a slowdown of 
power subsidence in digital flexor muscles of the hands, as one of the group of body muscles affected in ALS patients, who were administered FSCs along with the individual program of a complex of kinesiotherapy and respiratory gymnastics over a period from 6 to 18 months after treatment beginning, $(\mathrm{p}<0.05)$.

According to the analysis of the scores on the FIM scale in the patients who received combined treatment by use of FSCs and completed the individual program with a complex of kinesiotherapy and respiratory gymnastics, the study results prove a positive influence on sustaining functional independence of the patients with ALS ( $\mathrm{p}<0.05)$. The data received confirm that combined therapy by use of FSCs and completion of the individual program of a complex of kinesiotherapy and respiratory gymnastics have a positive effect on prolongation of average life expectancy among the patients $(\mathrm{p}<0.05)$.

\section{Acknowledgments}

All the authors of Cell Therapy Center EmCell contributed towards the study: "Combined Therapy Using Fetal Stem Cells and a Complex of Physical Exercises in Treatment of Patients with Amyotrophic Lateral Sclerosis" by making substantial contributions to its conception and materials analysis which was essential for our study.

My colleagues in Cell Therapy Center EmCell developed a design, actively participated in acquisition of data. All doctors were engaged in statistical analysis and interpretation of data obtained. The authors approved this manuscript and do agree to its publication.

\section{Competing interests}

The paper is intended to be an original paper; all authors of the manuscript are members of Cell Therapy Center EmCell, Kyiv, Ukraine. The authors have approved the manuscript and agree to its submission. There are no matters relevant to the conflict of interests among the authors who contributed to manuscript submission.

\section{References}

1. Kaspar BK (2008) Mesenchymal stem cells as trojan horses for GDNF delivery in ALS. Mol Ther 16: 1905-1906. [Crossref]

2. Rowland LP, Shneider NA (2001) Amyotrophic lateral sclerosis. N Engl J Med 344: 1688-1700. [Crossref]

3. Bruijn LI, Miller TM, Cleveland DW (2004) Unraveling the mechanisms involved in motor neuron degeneration in ALS. Annu Rev Neurosci 27: 723-749. [Crossref]

4. Wang H, Guan Y, Wang X, Smith K, Cormier K, et al. Nortriptyline delays disease onset in models of chronic neurodegeneration. Eur J Neurosci 26: 633-641. [Crossref]

5. Wang X (2009) The antiapoptotic activity of melatonin in neurodegenerative diseases. CNS Neurosci Ther 15: 345-357. [Crossref]

6. Li M, Ona VO, Guégan C, Chen M, Jackson-Lewis V, et al. (2000) Functional role of caspase-1 and caspase-3 in an ALS transgenic mouse model. Science 288: 335-339. [Crossref]

7. Zhu S, Stavrovskaya IG, Drozda M, Kim BY, Ona V, et al. (2002) Minocycline inhibits cytochrome $\mathrm{c}$ release and delays progression of amyotrophic lateral sclerosis in mice. Nature 417: 74-78. [Crossref]

8. Guan YJ, Wang X, Wang HY, Kawagishi K, Ryu H, et al. (2007) Increased stem cell proliferation in the spinal cord of adult amyotrophic lateral sclerosis transgenic mice. $J$ Neurochem 102: 1125-1138. [Crossref]

9. Rhodes J, Lutka FA, Jordan-Sciutto KL, Bowser R (2003) Altered expression and distribution of FAC1 during NGF-induced neurite outgrowth of PC12 cells. Neuroreport 14: 449-452. [Crossref]

10. Towne C, Setola V, Schneider BL, Aebischer P (2011) Neuroprotection by gene therapy targeting mutant SOD1 in individual pools of motor neurons does not translate into therapeutic benefit in fALS mice. Mol Ther 19: 274-283. [Crossref]
11. Liu J, Akhavan A, Lu M, Gruzman A, Lingappa VR, et al. (2010) Carbonic anhydrase I is recognized by an SOD1 antibody upon biotinylation of human spinal cord extracts. Int J Mol Sci 11: 4051-4062. [Crossref]

12. Liu-Yesucevitz L, Bilgutay A, Zhang YJ, Vanderwyde T, Citro A, et al. (2010) Tar DNA binding protein-43 (TDP-43) associates with stress granules: analysis of cultured cells and pathological brain tissue. PLoS One 5(10): e13250. [Crossref]

13. Turner MR, Hardiman O, Benatar M, Brooks BR, Chio A, et al. (2013) Controversies and priorities in amyotrophic lateral sclerosis. Lancet Neurol 12: 310-322. [Crossref]

14. Miller RG, Mitchell JD, Moore DH (2012) Riluzole for amyotrophic lateral sclerosis (ALS)/motor neuron disease (MND). Cochrane Database Syst Rev 3: CD001447. [Crossref]

15. Chen M, Valenzuela RM, Dhib-Jalbut S (2003) Glatiramer acetate-reactive T cells produce brain-derived neurotrophic factor. $J$ Neurol Sci 215: 37-44. [Crossref]

16. Angelov DN, Waibel S, Guntinas-Lichius O, Lenzen M, Neiss WF, et al. (2003) Therapeutic vaccine for acute and chronic motor neuron diseases: implications for amyotrophic lateral sclerosis. Proc Natl Acad Sci US A 100: 4790-4795. [Crossref]

17. Mhatre M, Floyd RA, Hensley K (2004) Oxidative stress and neuroinflammation in Alzheimer's disease and amyotrophic lateral sclerosis: common links and potential therapeutic targets. J Alzheimers Dis 6: 147-157. [Crossref]

18. Schwartz M, Kipnis J (2002) Autoimmunity on alert: naturally occurring regulatory CD4(+)CD25(+) T cells as part of the evolutionary compromise between a 'need' and a 'risk'. Trends Immunol 23: 530-534. [Crossref]

19. Maragakis NJ (2010) Stem cells and the ALS neurologist. Amyotroph Lateral Scler 11 417-423. [Crossref]

20. Papadeas ST, Maragakis NJ (2009) Advances in stem cell research for Amyotrophic Lateral Sclerosis. Curr Opin Biotechnol 20: 545-551. [Crossref]

21. Naegele JR, Maisano X, Yang J, Royston S, Ribeiro E (2010) Recent advancements in stem cell and gene therapies for neurological disorders and intractable epilepsy. Neuropharmacology 58: 855-864. [Crossref]

22. de Filippis L (2011) Neural stem cell-mediated therapy for rare brain diseases: perspectives in the near future for LSDs and MNDs. Histol Histopathol 26: 1093-1109. [Crossref]

23. Karussis D, Karageorgiou C, Vaknin-Dembinsky A, Gowda-Kurkalli B, Gomori JM, et al. (2010) Safety and immunological effects of mesenchymal stem cell transplantation in patients with multiple sclerosis and amyotrophic lateral sclerosis. Arch Neurol 67: 1187-1194. [Crossref]

24. Ren G, Chen X, Dong F, Li W, Ren X, et al. (2012) Concise review: mesenchymal stem cells and translational medicine: emerging issues. Stem Cells Transl Med 1: 5158. [Crossref]

25. Dezawa M, Kanno H, Hoshino M, Cho H, Matsumoto N,et al. (2004) Specific induction of neuronal cells from bone marrow stromal cells and application for autologous transplantation. J Clin Invest 113: 1701-1710. [Crossref]

26. Jiang J, Lv Z, Gu Y, Li J, Xu L, et al. (2010) Adult rat mesenchymal stem cells differentiate into neuronal-like phenotype and express a variety of neuro-regulatory molecules in vitro. Neurosci Res 66: 46-52. [Crossref]

27. Dodge JC, Treleaven CM, Fidler JA, Hester M, Haidet A, et al. (2010) AAV4-mediated expression of IGF-1 and VEGF within cellular components of the ventricular system improves survival outcome in familial ALS mice. Mol Ther 18: 2075-2084. [Crossref]

28. Acsadi G, Anguelov RA, Yang H, Toth G, Thomas R, et al. (2002) Increased survival and function of SOD1 mice after glial cell-derived neurotrophic factor gene therapy. Hum Gene Ther 13:1047-1059. [Crossref]

29. Pun S, Santos AF, Saxena S, Xu L, Caroni P (2006) Selective vulnerability and pruning of phasic motoneuron axons in motoneuron disease alleviated by CNTF. Nat Neurosci 9: 408-419. [Crossref]

30. Chen J, Li Y, Katakowski M, Chen X, Wang L, et al. (2003) Intravenous bone marrow stromal cell therapy reduces apoptosis and promotes endogenous cell proliferation after stroke in female rat. $J$ Neurosci Res 73: 778-786. [Crossref]

31. Gutierrez-Fernandez M, Fuentes B, Rodriguez-Frutos B, Ramos-Cejudo J, VallejoCremades MT, et al. (2012) Trophic factors and cell therapy to stimulate brain repair after ischaemic stroke. J Cell Mol Med 16: 2280-2290. [Crossref]

32. Forostyak S, Jendelova P, Kapcalova M, Arboleda D, Sykova E (2011) Mesenchymal stromal cells prolong the lifespan in a rat model of amyotrophic lateral sclerosis. Cytotherapy 13: 1036-1046. [Crossref] 
33. Vercelli A, Mereuta OM, Garbossa D, Muraca G, Mareschi K, et al. Human mesenchymal stem cell transplantation extends survival, improves motor performance and decreases neuroinflammation in mouse model of amyotrophic lateral sclerosis. Neurobiol Dis 31: 395-405. [Crossref]

34. Blanquer M, Moraleda JM, Iniesta F, Gomez-Espuch J, Meca-Lallana J, et al. (2012) Neurotrophic bone marrow cellular nests prevent spinal motoneuron degeneration in amyotrophic lateral sclerosis patients: a pilot safety study. Stem Cells 30:1277-1285. [Crossref]

35. Mundra V, Gerling IC, Mahato RI (2013) Mesenchymal stem cell-based therapy. Mol Pharm 10: 77-89. [Crossref]

36. Krakora D, Macrander C, Suzuki M (2012) Neuromuscular junction protection for the potential treatment of amyotrophic lateral sclerosis. Neurol Res Int 2012: 379657. [Crossref]

37. Zhao CP, Zhang C, Zhou SN, Xie YM, Wang YH, et al. (2007) Human mesenchymal stromal cells ameliorate the phenotype of SOD1-G93A ALS mice. Cytotherapy 9: 414426. [Crossref]

38. Uccelli A, Milanese M, Principato MC, Morando S, Bonifacino T, et al. (2012) Intravenous mesenchymal stem cells improve survival and motor function in experimental amyotrophic lateral sclerosis. Mol Med 18:794-804. [Crossref]

39. Marconi S, Bonaconsa M, Scambi I, Squintani GM, Rui W, et al. (2013) Systemic treatment with adipose-derived mesenchymal stem cells ameliorates clinical and pathological features in the amyotrophic lateral sclerosis murine model. Neuroscience 248C: $333-343$. [Crossref]

40. Suzuki M, McHugh J, Tork C, Shelley B, Hayes A, et al. (2008) Direct muscle delivery of GDNF with human mesenchymal stem cells improves motor neuron survival and function in a rat model of familial ALS. Mol Ther 16: 2002-2010. [Crossref]

41. Krakora D, Mulcrone P, Meyer M, Lewis C, Bernau K, et al. (2013) Synergistic effects of GDNF and VEGF on lifespan and disease progression in a familial ALS rat model. Mol Ther 21: 1602-1610. [Crossref]

42. 42. Carro E, Trejo JL, Busiguina S, Torres-Aleman I (2001) Circulating insulin-like growth factor I mediates the protective effects of physical exercise against brain insults of different etiology and anatomy. $J$ Neurosci 21(15): 5678-5684. [Crossref]

43. Carro E, Nuñez A, Busiguina S, Torres-Aleman I (2000) Circulating insulin-like growth factor I mediates effects of exercise on the brain. J Neurosci 20: 2926-2933. [Crossref]

44. Gómez-Pinilla F, Ying Z, Opazo P, Roy RR, Edgerton VR (2001) Differential regulation by exercise of BDNF and NT-3 in rat spinal cord and skeletal muscle. Eur J Neurosci 13: 1078-1084. [Crossref]

45. Kirkinezos IG, Hernandez D, Bradley WG, Moraes CT (2003) Regular exercise is beneficial to a mouse model of amyotrophic lateral sclerosis. Ann Neurol 53: 804-807. [Crossref]

46. Kaspar BK, Frost LM, Christian L, Umapathi P, Gage FH (2005) Synergy of insulinlike growth factor-1 and exercise in amyotrophic lateral sclerosis. Ann Neurol 57: 649655. [Crossref]

47. Liebetanz D, Hagemann K, von Lewinski F, Kahler E, Paulus W (2004) Extensive exercise is not harmful in amyotrophic lateral sclerosis. Eur J Neurosci 20: 3115-3120. [Crossref]

48. Carreras I, Yuruker S, Aytan N, Hossain L, Choi JK, et al. (2010) Moderate exercise delays the motor performance decline in a transgenic model of ALS. Brain Res 1313: 192-201. [Crossref]

49. Bello-Haas VD, Florence JM, Kloos AD, Scheirbecker J, Lopate G, et al. (2007) A randomized controlled trial of resistance exercise in individuals with ALS. Neurology 68: 2003-2007. [Crossref]

50. Drory VE, Goltsman E, Reznik JG, Mosek A, Korczyn AD (2001) The value of muscle exercise in patients with amyotrophic lateral sclerosis. J Neurol Sci 191: 133-137. [Crossref]

51. Norris FH Jr, Sang UK, Denys EH, Archibald KC, Lebo C (1978) Amyotrophic lateral sclerosis. Mayo Clin Proc 53: 544. [Crossref]

52. Bohannon RW (1983) Results of resistance exercise on a patient with amyotrophic lateral sclerosis. A case report. Phys Ther 63: 965-968. [Crossref]

53. Dalbello-Haas V, Florence JM, Krivickas LS (2008) Therapeutic exercise for people with amyotrophic lateral sclerosis or motor neuron disease. Cochrane Database Syst $\operatorname{Rev}(2)$ : CD005229. [Crossref]

54. Zimmerman EK, Eslinger PJ, Simmons Z, Barrett AM (2007) Emotional perception deficits in amyotrophic lateral sclerosis. Cogn Behav Neurol 20: 79-82. [Crossref]

55. http://www.rehabmeasures.org/Lists/RehabMeasures/DispForm.aspx?ID=1126

56. Kaufmann P, Levy G, Thompson JL, Delbene ML, Battista V, et al. (2005) The ALSFRSr predicts survival time in an ALS clinic population. Neurology 64: 38-43. [Crossref]

57. Andres PL, Hedlund W, Finison L, Conlon T, Felmus M, et al. (1986) Quantitative motor assessment in amyotrophic lateral sclerosis. Neurology 36: 937-941. [Crossref]

58. Andres PL, Thibodeau LM, Finison LJ, Munsat TL (1987) Quantitative assessment of neuromuscular deficit in ALS. Neurol Clin 5: 125-141. [Crossref]

59. Andres PL, Skerry LM, Thornell B, Portney LG, Finison LJ, et al. (1996) A comparison of three measures of disease progression in ALS. J Neurol Sci 139 Suppl: 64-70. [Crossref]

60. Hoagland RJ, Mendoza M, Armon C, Barohn RJ, Bryan WW, et al. (1997) Reliability of maximal voluntary isometric contraction testing in a multicenter study of patients with amyotrophic lateral sclerosis. Syntex/Synergen Neuroscience Joint Venture rhCNTF ALS Study Group. Muscle Nerve 20: 691-695. [Crossref]

61. Stineman MG, Jette A, Fiedler R, Granger C (1997) Impairment-specific dimensions within the Functional Independence Measure. Arch Phys Med Rehabil 78: 636-643. [Crossref]

62. Sych NS, Klunnyk MO, Sinelnyk AA, et al Patent \# 97540 for a Utility Model Amyotrophic lateral sclerosis treatment method with medicinal preparation from fetal material and cells harvested from it.

63. Zoccolella S, Beghi E, Palagano G, Fraddosio A, Guerra V, et al. (2008) Predictors of long survival in amyotrophic lateral sclerosis: a population-based study. J Neurol Sci 268: 28-32. [Crossref]

64. Martínez HR, Molina-López JF, Cantú-Martínez L, González-Garza MT, MorenoCuevas JE, et al. (2011) Survival and clinical features in Hispanic amyotrophic lateral sclerosis patients. Amyotroph Lateral Scler 12: 199-205. [Crossref]

65. Millul A, Beghi E, Logroscino G, Micheli A, Vitelli E, et al. (2005) Survival of patients with amyotrophic lateral sclerosis in a population-based registry. Neuroepidemiology 25: 114-119. [Crossref]

Copyright: (C2015 Sinelnyk AA. This is an open-access article distributed under the terms of the Creative Commons Attribution License, which permits unrestricted use, distribution, and reproduction in any medium, provided the original author and source are credited. 